\title{
Depresszív tüneteket és öngyilkossági gondolatokat befolyásoló tényezők gyulladásos bélbetegségben szenvedők körében
}

\author{
Multicentrikus tanulmány \\ Sánta Anett ${ }^{1}$ - Szántó Kata Judit dr. ${ }^{1}$ - Miheller Pál dr. ${ }^{2}$ \\ Sarlós Patrícia dr. ${ }^{3}$. Juhász Anita ${ }^{4}$. Hamvas Edina ${ }^{3}$ \\ Szegedi-Hallgató Emese dr. ${ }^{5}$. Farkas Klaudia dr. ${ }^{1}$ \\ Rafael Beatrix dr. ${ }^{5}$ - Molnár Tamás dr. ${ }^{1}$

\begin{abstract}
${ }^{1}$ Szegedi Tudományegyetem, Általános Orvostudományi Kar, I. Belgyógyászati Klinika, Szeged ${ }^{2}$ Semmelweis Egyetem, I. Sebészeti Klinika, Gasztroenterológiai Ambulancia, Budapest ${ }^{3}$ Pécsi Tudományegyetem, Klinikai Központ, I. Belgyógyászati Klinika, Pécs ${ }^{4}$ Semmelweis Egyetem, Általános Orvostudományi Kar, Klinikai Pszichológia Tanszék, Budapest ${ }^{5}$ Szegedi Tudományegyetem, Bölcsészettudományi Kar, Pszichológia Intézet, Szeged
\end{abstract}

Bevezetés: A gyulladásos bélbetegség olyan kórkép, mely a diagnózistól kezdve élethosszig hatással van a betegek fizikális és pszichés egészségi állapotára és életminőségére.

Célkitüzés: Megvizsgálni gyulladásos bélbetegek körében a depresszív tünetek és az öngyilkossági gondolatok előfordulásának gyakoriságát, valamint az ezekkel összefüggésben lévő betegség- és terápiaspecifikus tényezóket. Módszer: A vizsgálatban 300 fó vett részt (átlagéletkor 38,8 év, férfiak 47\%, nók 53\%). A depresszív tüneteket (PHQ-9), öngyilkossági gondolatokat (PHQ-9 9. tétele), a reménytelenség mértékét (Beck Reménytelenség Skála) és a betegséggel összefüggő jóllét mértékét (SIBDQ) vizsgáltuk online formában.

Eredmények: A vizsgálati személyek 28,6\%-a mutatott depresszív tüneteket, és 9,3\%-uk a magas rizikójú csoportba tartozik a reménytelenség tekintetében. Öngyilkossági gondolatokat a válaszadók 16\%-a jelzett, ebből magas rizikót a minta 5,3\%-a mutatott. A lineáris regressziós modell eredménye alapján a depresszív tüneteket magyarázó tényezők közé tartozik a reménytelenség mértéke, a bélen kívüli tünet fennállása, fájdalomcsillapító rendszeres szedése, a női nem, valamint a betegség aktivitása.

Következtetés: A vizsgálatunkban szereplő gyulladásos bélbetegek öngyilkossági gondolatainak és depresszív tüneteinek előfordulási aránya a nemzetközi adatokkal egyezően magas, amire kiemelt figyelmet érdemes fordítani a betegek pszichés vezetése során. A pszichológiai tényezők rendszeres vizsgálata és kezelése fontos része kell hogy legyen a betegek gondozásának, mivel javíthat a páciensek szubjektív állapotán, és a betegség lefolyására is pozitív hatással lehet.

Orv Hetil. 2020; 161(42): 1797-1805.

Kulcsszavak: gyulladásos bélbetegség, depresszió, öngyilkossági gondolatok

Influencing factors on depressive symptoms and suicidal ideation among inflammatory bowel disease patients

\section{Multicenter study}

Introduction: Inflammatory bowel disease is a chronic, relapsing disease that affects the physical and mental health and quality of life of patients from diagnosis.

Objective: The prevalence of depressive symptoms and suicidal ideation in inflammatory bowel disease patients as well as the associated disease and therapy specific factors were investigated. 
Method: The study included 300 subjects (mean age 38.8 years, men 47\%, women 53\%). Depressive symptoms (PHQ-9), suicidal ideation (PHQ-9 item 9), the degree of hopelessness (Beck Hopelessness Scale) and the healthrelated quality of life (SIBDQ) were evaluated with online, self-filling questionnaires.

Results: $28.6 \%$ of subjects showed depressive symptoms and $9.3 \%$ were at high risk for hopelessness. Suicidal ideation was reported by $16 \%$ of respondents, of which $5.3 \%$ reported high risk. According to the results of the linear regression model, factors that explain depressive symptoms include the degree of hopelessness, female gender, the presence of extraintestinal manifestations, taking painkillers regularly and disease activity.

Conclusion: The rate of suicidal ideation and the incidence of depression in our study sample are similar to international data. The activity of the disease affects the mood state of the individuals. Regular screening, insertion and treatment of psychological factors in the therapeutic process can improve the subjective status of patients and may also affect the course of the disease.

Keywords: inflammatory bowel diseases, depression, suicidal ideation

Sánta A, Szántó KJ, Miheller P, Sarlós P, Juhász A, Hamvas E, Szegedi-Hallgató E, Farkas K, Rafael B, Molnár T. [Influencing factors on depressive symptoms and suicidal ideation among inflammatory bowel disease patients. Multicenter study]. Orv Hetil. 2020; 161(42): 1797-1805.

(Beérkezett: 2020. április 28.; elfogadva: 2020. május 11.)

\section{Rövidítések}

5-ASA = 5-aminoszalicilát; 6-MP = 6-merkaptopurin; AZA = azatioprin; $\mathrm{CD}=$ (Crohn's disease) Crohn-betegség; EIM = (extraintestinal manifestation) bélen kívüli tünetek; IBD = (inflammatory bowel disease) gyulladásos bélbetegség; MTX = metotrexát; PHQ-9 = (Patient Health Questionnaire-9) 9 tételes, depressziót mérő kérdőív; $\mathrm{SD}=$ (standard deviáció) a minta szórása; SIBDQ $=($ Short Inflammatory Bowel Disease Questionnaire) Rövid Életminőség Kérdőív gyulladásos bélbetegségben; $\mathrm{UC}=$ (ulcerative colitis $)$ colitis ulcerosa; taj = társadalombiztosítási azonosító jel

A gyulladásos bélbetegség (IBD) olyan kórkép, mely a diagnózistól kezdve élethosszig hatással van a betegek fizikális és pszichés egészségi állapotára és életminőségére. A betegség lokalizációja, viselkedése, a bélen kívüli tünetek, a diagnózishoz szükséges és az utánkövetés során alkalmazott vizsgálóeljárások, kezelési formák, kórházi tartózkodások és esetleges sebészi beavatkozások mind jelentős mértékben érintik a betegek fizikai, pszichológiai és szociális állapotát $[1,2]$.

Korábbi vizsgálatok eredményei arra utalnak, hogy IBD esetén nagyobb gyakorisággal fordulnak elő az alapbetegséget kísérő pszichiátriai kórképek, mint a depresszió és a szorongásos zavarok. A depresszió és a szorongásos kórképek előfordulása és a betegség aktivitásának mértéke között pozitív irányú kapcsolat mutatkozik, és ez a kapcsolat valószínúleg kétirányú [3-6]. A depresszió jelentős hatással van az IBD kimenetelére, ami a szubjektív életminőséget, az egészségügyi ellátás igénybevételét és a kezelés hatékonyságát is érinti [6]. Egy lengyel vizsgálat szerint az IBD-s betegek körében a depresszió és a szorongás növekvő prevalenciája a bélgyulladás, az immunszabályozás zavara és az agy közötti kölcsönhatások komplex interakciójának következménye [7]. A Häuser és mtsai által végzett vizsgálatban a
IBD-khez társult pszichiátriai kórképek gyakorisága 37\% volt [4], míg kanadai betegek között a hangulatzavarok gyakoriságát 20,2-29,9\%-ra, a szorongásos kórképek gyakoriságát 24,9-31,6\%-ra becsülték [8]. Neuendorf és mtsai összefoglaló közleményükben a depresszív tünetek prevalenciáját 21,6\%-osnak, a depresszióét 15,2\%-osnak találták gyulladásos bélbetegek körében [9]. A legmagasabb előfordulási arányokat egy Franciaországban készült tanulmány mutatta, mely a gyulladásos bélbetegek $52 \%$ ánál valamilyen szorongásos kórképet, 44\%-ánál pedig depressziót mutatott ki [10].

Egy 2016-ban, fiatal amerikai felnőtt népesség körében végzett vizsgálat 8,8-9,6\% közöttinek találta a major depressziós epizód előfordulását [11], míg egy másik, 10 évig tartó keresztmetszeti kutatás az amerikai átlagnépesség körében 6,6-7,3\% között detektálta a depresszió előfordulását [12]. Walker és mtsai metaanalízise kórházban fekvő betegek körében 12\%-os összesített prevalenciaértéket talált [13].

Depresszió fennállása esetén gondolni kell az öngyilkossági gondolatok megjelenésére krónikus betegségben szenvedők körében is. Egy 2019-ben megjelent, az Amerikai Egyesült Államokban végzett felmérésben a vizsgált IBD-s populáció 5,25\%-ánál jelentek meg öngyilkossági gondolatok [14]. Egy másik, kifejezetten az öngyilkossági gondolatokat vizsgáló tanulmányban a megkérdezett gyulladásos bélbetegek 9,7\%-a nyilatkozott arról, hogy vannak ilyen gondolatai [15].

Kutatásunkban célul tűztük ki, hogy több vezető IBD-centrum betegeinek random kiválasztásával képet kapjunk a magyarországi, IBD-ben szenvedő felnőttek körében a depresszív tünetek és a reménytelenség érzésének gyakoriságáról, különös tekintettel az öngyilkossági rizikóra. Ezen túlmenően vizsgáltuk a depresszív tüneteket, a reménytelenségérzést és a betegségspecifikus, életminőséget befolyásoló tényezőket. 


\section{Módszer}

A vizsgálat során az online kérdőívet 300 fó töltötte ki (nemi megoszlás: férfi $47 \%$, nő $53 \%$ ), átlagéletkoruk 38,8 év (SD: 12,5) volt. A résztvevők három magyarországi felnőtt-IBD-centrum páciensei közül kerültek ki: Szegedi Tudományegyetem, I. Belgyógyászati Klinika (Szeged), Semmelweis Egyetem, I. Sebészeti Klinika, Gasztroenterológiai Ambulancia (Budapest) és Pécsi Tudományegyetem, I. Belgyógyászati Klinika (Pécs). Minden esetben az adott centrumban kezelt, gasztroenterológus által a nemzetközi kritériumok szerint diagnosztizált páciensek kerültek a vizsgálatba.

A mintába történő beválogatás feltételei a következők voltak:

- 18 és 65 év közötti férfi vagy nőbeteg;

- az IBD diagnózisának felállítása a klinikai tünetek, a radiológiai, az endoszkópos és a szövettani vizsgálatok alapján a bevonás előtt legalább három hónappal megtörtént;

- írásos beleegyező nyilatkozat kitöltése.

Kizárási kritériumok:

- 18 év alatti életkor;

- cselekvőképtelen, döntésképtelen vagy gondnokság alatt álló személy.

A résztvevők önkéntes alapon vettek részt a kitöltésben, informált beleegyezést kaptak a vizsgálatról, és aláírásukkal jelezték részvételi hajlandóságukat a beleegyező nyilatkozat elolvasásával és kitöltésével. A beválogatás kényelmi mintavétel alapján történt az ambulanciákon megjelenő betegek közül. A válaszadási arány 65\%-os volt. A kitöltött kérdőívek anonimak voltak, s egy, a taj szám első 3 jegyét és a kitöltő monogramját tartalmazó kódot kaptak.

\section{A vizsgálat menete}

A beleegyező nyilatkozatok aláírása után a kérdőívet minden résztvevő egyszer töltötte ki, ami körülbelül 20 percet vett igénybe.

Az első részben az alapadatok megadása után a kórelőzményre, kezelésre vonatkozó információk következtek (a betegség típusa, a kezelés módja, a diagnózis éve, mútét, gyógyszerszedés, szövődmények fennállása stb.). A kérdóív második része a depresszióra (PHQ-9), a reménytelenségérzésre (a Beck Reménytelenség Skála rövid változata) és az életminőségre (SIBDQ) vonatkozó kérdéseket tartalmazott.

\section{Méróeszközök}

1. Patient Health Questionnaire-9 (PHQ-9) depressziószürő kérdőív, amely 9 kérdéssel méri fel a páciensek depresszióra való hajlamát, és rákérdez az utolsó tétellel az öngyilkossági gondolatokra is. A kérdéseket 4 fokú skálán jelölhetik be a kitöltők, amelynek tartománya 0 és 3 közé esik. A magasabb pontszám a de- presszió valószínűségének magasabb fokát mutatja. A kérdőív értékei alapján 5 kategóriába sorolhatók az eredmények: nincs depresszió, enyhe, közepes, középsúlyos vagy súlyos depresszió $[16,17]$. A 9. tételre adott válaszok esetén minden, 0 -nál magasabb válasz prediktív értékü [15]. Az eredmények értelmezése során magas rizikónak tekintjük az 1 -nél magasabb érték jelölését [14]. A depresszió tekintetében a $\geq 10$ pontszámot elérók kerülnek a major depresszió diagnózisát kimerítő csoportba $[3,14,18]$.

2. A Beck Reménytelenség Skála rövidített változata 3 tételt tartalmaz, és 4 fokozatú skálán méri a kitöltő reménytelenségre vonatkozó érzéseit és motivációit. A reménytelenség kognitív komponensének mérése érdekében a Beck Depresszió Kérdőív 2. tételét is hozzáillesztettük a tesztbattériához, amely a kitöltő reménytelenségre irányuló gondolataira vonatkozik. A reménytelenség mérése így 4 tétellel történt, amit a kitöltő 0-3 fokozatú skálán értékelt tételenként. A Beck Reménytelenség Skála rövidített változata nagyon jó pszichometriai tulajdonságokkal rendelkezik, belső konzisztenciája kiváló (Cronbach-alfa: 0,85). A reménytelenség mértéke az öngyilkossági veszély egyik legfontosabb prediktorának tekinthető, 6 feletti pontszám prediktív értékű az öngyilkossági rizikó tekintetében. A továbbiakban a reménytelenségre vonatkozóan a Perczel-Forintos, Rózsa és Kopp által javasolt, 6 feletti értéket tekintjük magas rizikónak [19].

3. A Rövid Életminőség Kérdőív gyulladásos bélbetegek részére (SIBDQ) 10 tételen keresztül méri a betegek betegséggel kapcsolatos jóllétének különféle faktorait (béltünetek, szisztémás tünetek, érzelmek, szociális tényezők). Minden tétel 7 fokú skálán értékelhető, így a pontszámok 10 és 70 közé kerülnek. A magasabb pontszám jelzi a magasabb szubjektív jóllét mértékét $[20,21]$.

\section{Statisztikai elemzés}

Elemzésünkhöz az SPSS statisztikai program 20-as verzióját (IBM Corp., Armonk, New York, NY, USA) használtuk. A statisztikai próbák közül khi-négyzet-próbát, Pearson-féle korrelációt és lineáris regressziós elemzést végeztünk. Khi-négyzet-próbával hasonlítottuk össze az öngyilkossági gondolatok gyakoriságát és a depresszív tünetek mértékét egymással és a nemzetközi adatokkal, valamint saját adatainkon belül a betegségcsoportok között és a betegség aktivitási szintje szempontjából.

Pearson-korrelációval vizsgáltuk meg a depresszió és a betegséggel összefüggő életminőség közötti kapcsolatot, mivel a depresszió mértéke és a betegséggel összefüggő életminőség között erôs, negatív irányú együtt járás feltételezhető. Az életminőség ezért nem került bevonásra a depresszióra vonatkozó regressziós modellbe. Ezután külön regressziós elemzésben vizsgáltuk és hasonlítottuk össze, hogy a depresszió mértékére és az életminőségre mely változók hatnak. Ezáltal a depressziót leginkább 
befolyásoló, betegség- vagy terápiaspecifikus tényezők hatásai érvényesülhetnek. A regressziós elemzésből kizártuk azokat a válaszadókat, akik hiányosan töltötték ki a kérdőívet, vagy nem tudták egyértelműen meghatározni betegségük típusát. Ezek alapján mindkét modell 289 személy adatai alapján számolt. Az elemzéshez 'backward' módszert alkalmaztunk. A depresszió esetében függő változóként a PHQ-9 összpontszáma szerepelt. Független változóként a reménytelenség összpontszáma, az életkor, a betegség fennállásának ideje és a betegségre vonatkozó dichotóm változók kerültek be: nem, a betegség típusa, a betegség aktivitása, bélen kívü-

1. táblázat |A vizsgálatban részt vevő gyulladásos bélbetegek demográfiai jellemzői

\begin{tabular}{|c|c|c|c|c|c|c|c|c|c|}
\hline \multicolumn{10}{|c|}{ Az összes válaszadóra vonatkozó adatok $(\mathrm{n}=300)$} \\
\hline Résztvevők (N/F) & \multicolumn{4}{|c|}{$159(53 \%)$} & \multicolumn{5}{|c|}{$141(47 \%)$} \\
\hline Átlagéletkor & \multicolumn{9}{|c|}{38 év $(S D=12,5)$} \\
\hline Betegségben töltött átlagos idő & \multicolumn{9}{|c|}{11,5 év $(S D=8,2)$} \\
\hline \multirow[t]{2}{*}{ A betegség típusa } & UC & \multicolumn{3}{|c|}{$\mathrm{CD}$} & \multicolumn{3}{|c|}{ Nem tudja } & \multicolumn{2}{|c|}{ Nem meghatározott } \\
\hline & $36 \%$ & \multicolumn{2}{|c|}{$61 \%$} & & \multicolumn{3}{|c|}{$2,3 \%$} & \multicolumn{2}{|l|}{$0,3 \%$} \\
\hline \multirow[t]{2}{*}{ Biológiai terápia } & Soha & \multicolumn{6}{|c|}{ Korábban igen } & \multicolumn{2}{|c|}{ Jelenleg is } \\
\hline & $19,7 \%$ & \multicolumn{6}{|c|}{$26,7 \%$} & \multicolumn{2}{|l|}{$53 \%$} \\
\hline \multirow[t]{2}{*}{ Gyógyszeres terápiák } & 5-ASA per os & \multicolumn{2}{|c|}{ AZA, 6-MP, MTX } & $\begin{array}{r}\mathrm{SC} \\
\mathrm{t}\end{array}$ & $\begin{array}{l}\text { iológiai } \\
\text { rápia }\end{array}$ & $\begin{array}{c}\text { Iv. } \\
\text { biológiai } \\
\text { terápia }\end{array}$ & $\begin{array}{l}\text { Lokális } \\
\text { terápia }\end{array}$ & Metilprednizolon & Budezonid \\
\hline & $38,7 \%$ & \multicolumn{2}{|c|}{$35,7 \%$} & \multicolumn{2}{|c|}{$29,3 \%$} & $24,3 \%$ & $17,3 \%$ & $7,3 \%$ & $4,6 \%$ \\
\hline \multicolumn{10}{|c|}{ Típus szerinti eloszlások $(\mathrm{UC}, \mathrm{n}=109 ; \mathrm{CD}, \mathrm{n}=183$ ) } \\
\hline Szövödmény & Nincs & \multicolumn{6}{|c|}{ Szükület } & \multicolumn{2}{|c|}{ Sipoly } \\
\hline Összes & $52,3 \%$ & \multicolumn{6}{|c|}{$29,3 \%$} & $18,3 \%$ & \\
\hline $\mathrm{CD}$ & $30,1 \%$ & & & & $43,2 \%$ & & & $26,8 \%$ & \\
\hline $\mathrm{UC}$ & $88,1 \%$ & & & & $8,3 \%$ & & & $3,7 \%$ & \\
\hline Lokalizáció & Vékonybél & $\begin{array}{l}\text { Vastagbél } \\
\text { egy része }\end{array}$ & $\begin{array}{r}\text { Telj } \\
\text { vastag }\end{array}$ & & $\begin{array}{c}\text { Vékony- } \\
\text { és } \\
\text { vastagbél }\end{array}$ & & 'gbél & Felső tápcsatorna & Nem tudja \\
\hline Összes & $10,33 \%$ & $25,33 \%$ & 25 & & $33 \%$ & & $6 \%$ & $0,3 \%$ & $2 \%$ \\
\hline $\mathrm{CD}$ & $16,4 \%$ & $15,3 \%$ & 9 , & & $51,9 \%$ & & $8 \%$ & $0,5 \%$ & $2,1 \%$ \\
\hline $\mathrm{UC}$ & - & $42,2 \%$ & 50 & & - & & $4 \%$ & - & $1 \%$ \\
\hline Mütét & & $\mathrm{Nem}$ & & & & & & & \\
\hline Összes & & $55,7 \%$ & & & & & & & \\
\hline $\mathrm{CD}$ & & $38,3 \%$ & & & & & & & \\
\hline $\mathrm{UC}$ & & $83,5 \%$ & & & & & & & \\
\hline Bélen kivüli tünet & & Nem & & & & & & & \\
\hline Összes & & $48 \%$ & & & & & & & \\
\hline $\mathrm{CD}$ & & $48,1 \%$ & & & & & & & \\
\hline $\mathrm{UC}$ & & $51,4 \%$ & & & & & & $6 \%$ & \\
\hline Fájdalomcsillapitó szedése & & Nem & & & & & & & \\
\hline Összes & & $91,3 \%$ & & & & & & & \\
\hline $\mathrm{CD}$ & & $90,2 \%$ & & & & & & & \\
\hline $\mathrm{UC}$ & & $92,7 \%$ & & & & & & & \\
\hline Aktivitás & & Relapsus & & & & & Rer & sszió & \\
\hline Összes & & $30,7 \%$ & & & & & & & \\
\hline $\mathrm{CD}$ & & $28,4 \%$ & & & & & & & \\
\hline $\mathrm{UC}$ & & $34,9 \%$ & & & & & & & \\
\hline Nyugtató szedése & & $\mathrm{Nem}$ & & & & Igen & & Alkalmank & ént \\
\hline Összes & & $86,7 \%$ & & & & $6 \%$ & & $7,3 \%$ & \\
\hline $\mathrm{CD}$ & & $87,4 \%$ & & & & $4,9 \%$ & & $7,7 \%$ & \\
\hline $\mathrm{UC}$ & & $86,2 \%$ & & & & $6,4 \%$ & & $7,3 \%$ & \\
\hline
\end{tabular}

5-ASA = 5-aminoszalicilát; 6-MP = 6-merkaptopurin; $\mathrm{AZA}=$ azatioprin $; \mathrm{CD}=$ Crohn-betegség; iv. = intravénás; $\mathrm{MTX}=$ metotrexát $; \mathrm{SC}=$ subcu$\tan ; \mathrm{UC}=$ colitis ulcerosa 
li tünetek jelenléte, rendszeres nyugtató- és fájdalomcsillapító-szedés, a kezelés során jelentkező esetleges mellékhatások észlelése, valaha kapott-e biológiai terápiát, vagy jelenleg kap-e. A másik regressziós modellben függő változóként a SIBDQ-összpontszám szerepelt. Független változóként a reménytelenség összpontszáma, az életkor, betegség fennállásának ideje és a betegségre vonatkozó dichotóm változók kerültek be: nem, a betegség típusa, a betegség aktivitása, bélen kívüli tünetek jelenléte, rendszeres nyugtató- és fájdalomcsillapító-szedés, a kezelés során jelentkező esetleges mellékhatások észlelése, valaha kapott-e biológiai terápiát, vagy jelenleg kap-e.

\section{Eredmények}

\section{Demográfiai adatok}

A részletes demográfiai adatokat az 1. táblázat tartalmazza. A keresztmetszeti kutatás összesen 300 személy - 159 nő (53\%) és 141 férfi (47\%) - válaszát tartalmazza. A résztvevők átlagéletkora 38 év (SD: 12,5). A betegség típusa szerint 109 (36\%), colitis ulcerosa (UC) diagnózisával rendelkező beteg van a mintában, 183 Crohn-beteg (CD) (61\%); 7 személy nem tudja egyértelmúen megmondani betegsége típusát $(2,3 \%), 1$ válaszadó pedig nem meghatározott típusba sorolható $(0,3 \%)$. A megkérdezettek körében az átlagos betegségfennállási idő 11,5 év (SD: 8,2). A vizsgálat időpontjában a megkérdezettek 69,3\%-ánál saját vélemény szerint a betegség remisszióban volt, míg 30,7\%-nál a betegség aktivitási tünetei álltak fenn. A betegek 52,3\%-ánál nem jelentkezett IBD okozta szövődmény, míg 29,3\%-nál bélrendszert érintő szúkület, 18,3\%-nál sipoly volt jelen. Bélen kívüli tünetről a vizsgálatban részt vevók $52 \%$-a számolt be.

\section{Gyógyszeres terápia}

5-aminoszalicilát (5-ASA) per os kezelésben részesültek 116-an (38,7\%), immunszuppresszív (azatioprin [AZA]/6-merkaptopurin [6-MP]/metotrexát [MTX]) terápiában a betegek $35,7 \%$-a; a résztvevők 29,3\%-a subcutan biológiai terápiában (adalimumab vagy usztekinumab), 24,3\%-a intravénás biológiai terápiában (infliximab vagy vedolizumab), 7,3\%-a metilprednizolon-kezelésben, míg 4,6\% budezonidkezelésben részesült a vizsgálat idejében. Az aktuálisan biológiai terápiában nem részesülő betegek közül nem kapott soha biológiai terápiát 59 személy (19,7\%); korábban már kapott 80 fó $(26,7 \%)$.

\section{Öngyilkossági rizikó}

A megkérdezett gyulladásos bélbetegek 9,3\%-a jelzett magas rizikót (a Beck Reménytelenség Skála rövid változata szerint $>6$ ) a reménytelenség tekintetében. A betegség aktivitása szempontjából a nyugalmi állapotban lévők 6,7\%-ánál, míg az aktív betegséggel küzdők 15,3\%-ánál mutatott határérték feletti pontszámot a kérdőív. A továbbiakban a Beck Reménytelenség Skála rövidített változatának eredményei a regressziós modell részeként jelennek meg.

Az öngyilkossági rizikó az áltatunk vizsgált, magyar multicentrikus mintában 16\%-nak bizonyult, magas rizikót mutatott a betegek 5,3\%-a (a PHQ-9 9. tételére adott válasz $>1)$. Az öngyilkossági rizikó gyakoriságára vonatkozó khi-négyzet-próba eredménye: $\chi^{2}(1)=0,06$, $\mathrm{p}=0,937$. A CD-s és UC-s betegek esetében nem találtunk különbséget az öngyilkossági rizikó tekintetében $\chi^{2}(1)=0,883, p=0,347$. Továbbá a betegség aktivitása szempontjából sincs jelentős különbség az öngyilkossági rizikó gyakoriságában a relapsusban és a remisszióban lévő csoportok között: $\chi^{2}(1)=1,255, \mathrm{p}<0,263$. Tehát csupán a PHQ-9 9. tételére adott válaszok alapján az aktív betegséggel élők és a nyugalmi állapotban lévők statisztikailag nem különböztek egymástól.

Összehasonlítottuk a major depresszió diagnózisát kimerítő (>10 pont) pontszámmal rendelkező személyeket az öngyilkossági rizikót jelölőkkel. A 0-tól eltéró értékkel rendelkező, öngyilkossági gondolatokra utaló válaszok esetében a válaszadók 75\%-a tartozott a depressziós csoportba. Az 1-nél nagyobb öngyilkossági pontszámot jelölők között 1 személy kivételével mindenki megjelent a depressziós csoportban is. Az öngyilkossági rizikót magyarázó tényezőket a továbbiakban nem vizsgáltuk külön, mivel az elemzés során azt találtuk a saját mintánkban, hogy az öngyilkossági rizikó leginkább a depresszió fennállásától függ, így a mögöttes változók tekintetében is azok kerülnének felszínre, amelyek a depresszióra is hatással vannak (2. táblázat).

\section{Depresszió}

A válaszadók 28,6\%-a mutatja a major depresszió jeleit. A depresszió gyakoriságát vizsgáló khi-négyzet-próba eredménye: $\chi^{2}(1)=1,584, p=0,208$. A CD-s és UC-s betegek depressziószintjét is megvizsgáltuk. Eredmé-

\begin{tabular}{l|l} 
2. táblázat & $\begin{array}{l}\text { Alacsony és magas rizikójú öngyilkossági válaszokat adók és a } \\
\text { major depresszió valószínúségét jelzó személyek válaszainak el- } \\
\text { oszlásai }\end{array}$
\end{tabular}

\begin{tabular}{|c|c|c|c|}
\hline & & \multicolumn{2}{|c|}{ Öngyilkossági gondolatok (>0) } \\
\hline & & Nem & Igen \\
\hline \multirow[t]{2}{*}{ Depresszió } & Nem & $201(80 \%)$ & $12(25 \%)$ \\
\hline & Igen & $50(19,9 \%)$ & $36(75 \%)$ \\
\hline \multirow[t]{3}{*}{ Összes } & & $251(100 \%)$ & $48(100 \%)$ \\
\hline & & \multicolumn{2}{|c|}{ Öngyilkossági gondolatok (>1) } \\
\hline & & Nem & Igen \\
\hline \multirow[t]{2}{*}{ Depresszió } & Nem & $212(74,91 \%)$ & $1(6,25 \%)$ \\
\hline & Igen & $71(25,08 \%)$ & $15(93,75 \%)$ \\
\hline Összes & & $283(100 \%)$ & $16(100 \%)$ \\
\hline
\end{tabular}




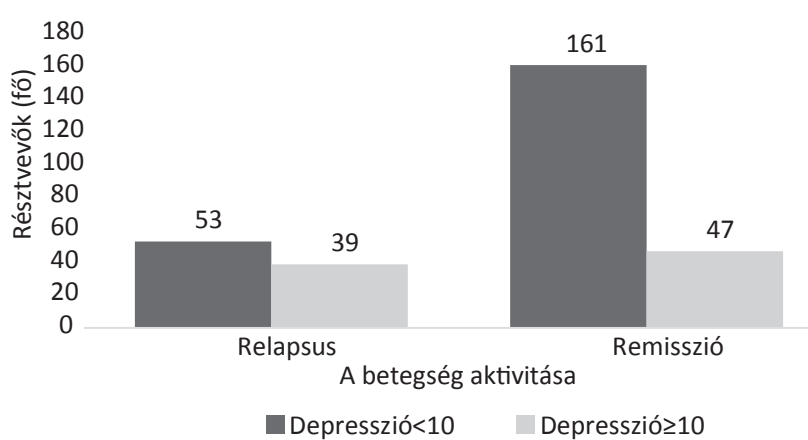

1. ábra

A depresszió előfordulási aránya a betegség aktivitásának tükrében

nyeink alapján nem találtunk különbséget a két csoport között: $\chi^{2}(1)=0,140, p=0,708$. A betegség aktivitása szerint viszont jelentős különbség van a remisszióban és a relapsusban lévők depresszív tüneteinek előfordulási gyakoriságában. A PHQ-9 kérdőív összpontszámát tekintve már statisztikailag kimutatható eltérés van a relapsusban és a remisszióban lévők között. Az aktív betegségben küzdők 42,4\%-a, míg a nyugalmi állapotban lévők 22,6\%-a mutat depresszív tüneteket (1. ábra). A próba eredménye: $\chi^{2}(1)=12,223, \mathrm{p}<0,001$.

Az életminőség és a depresszió együttes előfordulását vizsgáló korreláció eredménye: $\mathrm{r}(290)=-0,739$, $\mathrm{p}<0,001$. A két változó magas korrelációja miatt az életminőséget nem tettük bele a depressziót vizsgáló regressziós modellbe, mert a magas együtt járás jelentősen torzíthatta volna az egyes tényezők szerepét a depresszió esetén. Célunk a mögöttes magyarázó tényezők feltárása volt, a betegséghez kapcsolódó életminőség pedig vélhetően szintén ezen tényezőkkel mutat kapcsolatot.

A következőkben a depresszív tüneteket meghatározó tényezőket vizsgáltuk meg. A lineáris regressziós analízis eredménye: $\mathrm{R}^{2}=0,541, \mathrm{~F}(5)=66,642, \mathrm{p}<0,001$. A statisztikai próba eredménye alapján az alábbi változók kaptak helyet a regressziós modellben: a válaszadó neme, a betegség aktivitása, bélen kívüli tünetek jelenléte, fájdalomcsillapító szedése és a reménytelenségérzés mértéke. Tehát a modell szerint a depresszív tünetek előfordulását 54,1\%-ban magyarázzák a felsorolt tényezők. A legerősebb magyarázó erővel a reménytelenség mértéke rendelkezett $(\beta=0,591, p<0,001)$. A reménytelenség tekintetében egyenes arányú változás várható: ha a reménytelenség mértéke növekszik, a depresszió szintje is növekedni fog. A következő változó a bélen kívüli tünetek jelenléte $(\beta=0,158, \mathrm{p}<0,001)$, ami azt jelenti, hogy bármilyen, bélen kívüli tünet fennállása a depreszszió mértékének növekedésével jár. A rendszeres fájdalomcsillapító-szedés $(\beta=0,139, \mathrm{p}=0,002)$ esetén is egyenes irányú a hatás, jelenléte a depressziószint emelkedését okozhatja. Ezt követi a válaszadó neme ( $\beta=$ $0,100, \mathrm{p}=0,015)$, mely szerint a nói nem magasabb depressziószintet feltételez. Továbbá erôs tendenciaként végül a betegség aktivitása is a modell részét képezi $(\beta=$
-0,074, p = 0,075). Ez az egyetlen negatív előjelú változó, mivel a válaszok között a remisszió a magasabb értékkel kódolt válasz (relapsus $=1$; remisszió $=2$ ). Ez alapján, amennyiben remisszióban van a beteg, úgy a depresszió mértékében is csökkenés várható.

További elemzésünkben azt is szerettük volna megvizsgálni, hogy az életminőségre hogyan hatnak ugyanezen változók. Bár magas korrelációt találtunk a depreszszió és az életminőség között, előfordulhat, hogy bizonyos faktorok specifikusan hatnak a depresszióra. Az életminőségre vonatkozó lineáris regressziós modell eredménye: $\mathrm{R}^{2}=0,507, \mathrm{~F}(6)=48,288, \mathrm{p}<0,001$. A következő változók kerültek a modellbe: életkor, a betegség aktivitása, bélen kívüli tünetek jelenléte, fájdalomcsillapító szedése, a reménytelenségérzés mértéke, valamint hogy kapott-e biológiai terápiát bármikor a válaszadó. Tehát a modell szerint az életminőséget 50,7\%-ban magyarázzák a felsorolt tényezők. Az életminőség esetében elvégzett regressziós elemzés a válaszadó nemére vonatkozó változó kivételével beemelte a modellbe a másik 4 független változót, amelyek a depresszió regressziós modelljében is szerepelnek, viszont ebben a változók hatásai ellentétes előjelűek. Ezenkívül megjelennek az aktuális életminőségre kialakított modell részeként az életkor és a biológiai terápiát már valaha kapott bélbetegek adatai. A két modell összehasonlító vizsgálatát a 3. táblázat mutatja be.

3. táblázat $\mid$ A depresszív tüneteket és az életminőséget előre jelző tényezők összehasonlítása (lineáris regressziós modell)

\begin{tabular}{|c|c|c|c|c|}
\hline & & B-érték & $\operatorname{Beta}(\beta)$ & p-érték \\
\hline Függố változó & Depresszió (PHQ-9) & & & \\
\hline \multirow{5}{*}{$\begin{array}{l}\text { Független } \\
\text { változók }\end{array}$} & Reménytelenségérzés & 1,149 & 0,591 & $<0,001$ \\
\hline & $\begin{array}{l}\text { Bélen kívüli tünetek } \\
\text { (EIM) }\end{array}$ & 1,555 & 0,158 & $<0,001$ \\
\hline & $\begin{array}{l}\text { Fájdalomcsillapító } \\
\text { szedése }\end{array}$ & 2,386 & 0,139 & 0,002 \\
\hline & Nem & 0,987 & 0,100 & 0,015 \\
\hline & A betegség aktivitása & $-0,792$ & $-0,074$ & 0,075 \\
\hline Függő változó & Életminőség (SIBDQ) & & & \\
\hline \multirow{6}{*}{$\begin{array}{l}\text { Független } \\
\text { változók }\end{array}$} & Reménytelenségérzés & $-1,960$ & $-0,405$ & $<0,001$ \\
\hline & A betegség aktivitása & 8,625 & 0,325 & $<0,001$ \\
\hline & $\begin{array}{l}\text { Bélen kívüli tünetek } \\
\text { (EIM) }\end{array}$ & $-4,375$ & $-0,179$ & $<0,001$ \\
\hline & $\begin{array}{l}\text { Fájdalomcsillapító } \\
\text { szedése }\end{array}$ & $-6,393$ & $-0,149$ & 0,001 \\
\hline & Életkor & 0,114 & 0,091 & 0,032 \\
\hline & $\begin{array}{l}\text { Biológiai terápiát már } \\
\text { kapott }\end{array}$ & $-2,212$ & $-0,080$ & 0,064 \\
\hline
\end{tabular}

EIM = bélen kívüli tünetek; PHQ-9 = 9 tételes, depressziót mérő kérdőív; SIBDQ = Rövid Életminőség Kérdőív gyulladásos bélbetegségben 


\section{Megbeszélés}

A korábbi vizsgálatok eredményei magasnak találták a depresszió előfordulását IBD esetén $[18,22]$, egyes vizsgálatok háromszor magasabb arányt feltételeznek az átlagpopulációhoz viszonyítva [11, 12, 23]. Vizsgálatunkban ezért három magyarországi IBD-centrumban kezelt páciensek depresszióra és öngyilkossági gondolatokra vonatkozó adatait vizsgáltuk. A vizsgált változók előfordulási gyakorisága mellett a depressziót és az öngyilkossági gondolatokat befolyásoló tényezők hatásait is elemeztük. Eredményeink szerint az öngyilkossági gondolatok előfordulási aránya magas a kitöltők között, ami statisztikai szempontból nem tért el a Hashash és $m$ tsa $i$ keresztmetszeti vizsgálatában kapott 5,25\%-os elöfordulástól [14]. Fontos ugyanakkor, hogy más szakirodalmak ettől eltérő eredményekről számolnak be [15]. Az öngyilkossági rizikó IBD-s fiatalok körében a három leggyakoribb, mortalitást jelentő ok között szerepel egy skandináv vizsgálat szerint [24]. A Zhang és mtsai által publikált metaanalízis alapján a IBD-vel élők körében magasabb öngyilkossági rizikó feltételezhető az átlagnépességhez képest [25]. Ennek tükrében már fiatal betegeknél, a betegség kezdetétól és utána is fontos feladat a rendszeres szûrés. A pszichés terheltség, a pszichiátriai zavarok felismerése és a betegek megfelelő ellátáshoz történő irányítása jelentősen mérsékelhetné az öngyilkossági rizikó miatti mortalitást.

A depresszió előfordulási gyakorisága saját eredményeink szerint $28,6 \%$, ami statisztikai szempontból nem tér el Byrne és mtsai eredményétől [18]. További külföldi kutatások is hasonló eredményeket publikáltak gyulladásos bélbetegek körében $[8,26,27]$. Kevés átfogó vizsgálat áll rendelkezésre, de egy 2017-es metaanalízis 7-59\% közöttinek becsüli gyulladásos bélbetegek körében a depresszió előfordulását [28], míg serdülők körében 15\%-os összevont prevalenciát találtak [29]. Magyar egészségügyi adatok szerint a lakosság negyedénél jelenik meg valamilyen depresszív tünet, súlyos depressziót 3,5\%-ban találtak [30]. Az IBD-vel kezelt betegek esetében észlelt, közel 30\%-os major depressziós arány ennek sokszorosa, ami jelzi, hogy ennek a krónikus betegségnek a szomatikus tüneteken túl jelentős hatása van a betegek pszichés állapotára is.

Egy 2012-es magyar tanulmány szerint az asztmás betegekhez és az egészséges személyekhez képest a megélt életminőség tekintetében az IBD-s betegek szignifikánsan alacsonyabb értékeket mutattak. Ezt a betegség sajátos terheivel, a társas helyzetektől való izolációval és az érzelmi stabilitás fenntartásának nehézségeivel magyarázták [31]. Saját eredményeink szerint a depresszió és az életminőség között erős negatív korreláció mutatható ki, tehát az egyiknek a pozitív irányú változása a másik ellentétes irányú elmozdulását vonja maga után. A hangulati zavarok befolyásolják a kezelés hatékonyságát és az életminőséget is $[8,27]$.
Saját eredményeinkben a depresszióra vonatkozó lineáris regressziós analízis egy 5 tényezőből álló modellt alakított ki. A modell szempontjából a legnagyobb magyarázó erővel a reménytelenségérzés magas szintje szerepelt, ezután a bélen kívüli tünetek fennállása, fájdalomcsillapító rendszeres szedése, majd a válaszadó neme, valamint tendenciaként a betegség aktivitása szerepelt. Tehát a magasabb reménytelenségérzés, bármilyen bélen kívüli tünet fennállása, a tartós vagy intenzív fájdalom miatti rendszeres fájdalomcsillapító-szedés, valamint a válaszadó neme és a betegség fellángolása nagymértékben hatással van a betegek lelkiállapotára, ami a depreszszív tünetek kialakulását, súlyosbodását okozhatja.

A gyulladásos bélbetegek élethosszig tartó betegségfolyamattal, annak minden testi, lelki és szociális vonatkozásával, valamint megjósolhatatlan, hullámzó lefolyással néznek szembe. Perczel és mtsai megállapításai szerint a szubjektív egészségi állapot romlása és a depresszív tünetek fokozott reménytelenségérzést válthatnak ki [19]. Az általunk vizsgált bélbetegek esetében is elmondható, hogy a reménytelenségérzés jelenléte mind a depresszív tünetek, mind a rosszabb szubjektív állapot mögött megtalálható mint magyarázó változó, és jelenős hatással rendelkezik. Egy 2019-es vizsgálat szerint a gyakori alhasi fájdalom több fájdalomcsillapító-szedéssel és a depresszió magasabb előfordulásával jár [32]. Ezzel saját eredményeink is összhangban vannak, mivel a rendszeres fájdalomcsillapító-szedés is megjelenik mindkét modellben, és fennállása rosszabb állapotot feltételez. Egy 2018-as vizsgálat a mütéti előzményeket, a betegség szövődményeit (bélen kívüli tünetek is), a dohányzást és a nói nemet találta a depresszióval összefüggésben [33]. A bélen kívüli tünetek fennállása mindkét modellünkben szerepel, a női nem viszont csupán a depressziót magyarázó modell része. Végül a betegség aktivitása is megjelenik mindkét, általunk felállított modellben. A fellángolás meghatározó a depresszív tünetek megjelenése szempontjából IBD-ben $[5,9]$, viszont az aktuális életminőséget is jelentősen rontja [27]. Egyes vizsgálatok szerint a depresszió IBD-ben a betegség súlyosságától függetlenül is rontja az életminőséget [18]. Egy 2007-es magyar vizsgálat szerint viszont az IBD-s betegek pszichés problémái a betegség aktivitásának következményeként értelmezhetők [34]. Saját eredményeink szerint mindkét változóra hatással van a betegség aktivitása. A betegség pillanatnyi aktivitása megjelenik a depressziót meghatározó modellben, viszont nem idézett elő szükségszerűen öngyilkossági gondolatokat - az utóbbiak valószínúleg sokkal inkább a krónikus elkeserítő állapot eredményei. Az általunk megkérdezett gyulladásos bélbetegek körében az aktuálisan depresszív tünetet jelző személyek aránya jelentősen magasabb az öngyilkossági gondolatokat jelzőknél. Az öngyilkossági gondolatokat inkább a depresszió súlyossága befolyásolja, és kevésbé hat rá a betegség aktivitása [14]. Ezzel magyarázható, hogy a betegség aktivitása szempontjából az öngyilkossági gondolat esetében nem tért el a két csoport, míg a 
depresszióra vonatkozóan megjelent a különbség. Vizsgálatunk nem mutatott különbséget a CD-s és UC-s betegek depressziójának mértéke között. Külföldi adatok viszont a CD-s betegek körében gyakrabban találtak magasabb depressziópontszámokat [9, 27].

A regressziós modellek összehasonlítása alapján a két függő változót hasonló tényezők magyarázzák. Tehát az általunk megkérdezettek között a depresszív tünetek megjelenését és a szubjektív életminőséget hasonló tényezők befolyásolják. Megállapítható, hogy IBD-ben a klinikai szintű depresszió és az ennek következtében esetlegesen megjelenő öngyilkossági gondolatok jelentős hatást gyakorolhatnak a többi változón keresztül az életminőségre. Különbségként jelent meg a két modell között, hogy a válaszadó neme csupán a depressziót vizsgáló modellben szerepel. IBD-s nőbetegek körében korábban is magasabbnak találták a depresszió előfordulását $[23,33]$. Tehát míg a depresszióra hatása van a bélbeteg nemének, addig a szubjektív életminőségre nem hat ez a változó. Ezt a későbbi depressziót célzó prevenciók és intervenciók esetében is érdemes figyelembe venni, mivel a nói nem rizikócsoportnak tekinthető a depresszió szempontjából.

A folyamatok kétirányúsága miatt a depresszió kezelése és/vagy a betegség aktivitásának visszaszorítása hatással lehet a betegek szubjektív életminőségére is $[6,35]$. A nem vagy aluldiagnosztizált komorbid pszichiátriai zavarok, mint a depresszió, hosszú távon jelentős terhet jelentenek a gyulladásos bélbetegekre és az óket kezelő egészségügyi ellátórendszerre is [36]. Összefoglalásként elmondható, hogy a gyulladásos bélbetegek esetében a pszichés komorbiditás, ezen belül a depresszió, az öngyilkossági gondolatok szürése a saját vizsgálatunkban és a szakirodalomban talált magas elófordulás miatt a betegek hosszú távú kezelése és életminőségük szempontjából is kiemelt jelentőségú. A kezeletlen pszichés állapotok rövid és hosszú távon is jelentős hatással lesznek a betegek szomatikus állapotára, betegségük lefolyására és annak ütemére is, mind az önmenedzselés, mind az orvos-beteg kapcsolat szempontjából, kiemelten a betegség fellángolásának időszakában. Az öngyilkossági prevenció szempontjából is kiemelt jelentőségú a betegek pszichés állapotának nyomon követése és a rizikó csökkentése, mivel a betegség terhei jelentős súlyt helyeznek minden páciensre.

\section{A vizsgálat korlátai}

A vizsgálat korlátai közé tartozik, hogy az önkitöltős kérdőívek gyors és hatékony felvétele ellenére hiányoznak a páciensekkel a személyes benyomások, amelyek a depresszió és az egyéb pszichológiai problémák esetében is kifejezetten informatívak és fontosak a szakemberek szempontjából. Továbbá az önkitöltő kérdőív a betegségre, a betegség aktivitására, a terápiával kapcsolatos kérdésekre adott válaszok valódiságát nem tudja teljes mértékben garantálni. Valamint a kérdőív nem tért ki a pszichiátriai elözményekre, csupán a nyugtatószedési szokásokra kérdeztünk rá. A kérdőív rövidsége az adatok korlátozottságával jár együtt, viszont a hosszú kitöltési idő szintén rontja a kitöltési hajlandóságot. További IBD-centrumok bevonása és a minta elemszámának növelése még pontosabbá tenné a témához tartozó következtetéseket. További vizsgálatok szükségesek az IBD-s páciensek depresszív tüneteinek és az azokat befolyásoló személyes és interperszonális tényezóknek a vizsgálatához a mindennapi, multidiszciplináris gyakorlat hatékonnyá tétele érdekében. A vizsgálatban öngyilkossági rizikót jelző páciensek esetében jelzés, további szürés és a megfelelő szakemberhez történő irányítás szükséges a vizsgálat logikus folytatásaként állapotuk stabilizálása érdekében.

Anyagi támogatás: A közlemény megírása anyagi támogatásban nem részesült.

Szerzői munkamegosztás: A vizsgálat előkészítése: M. T., Sz. K. J., S. A. Adatgyüjtés: Sz. K. J., S. A., M. P., S. P., J. A., H. E. Adatelemzés: S. A., Sz. K. J., Sz.-H. E. A kézirat szövegezése: S. A., Sz. K. J. A szöveg átnézése: S. A., Sz. K. J., M. P., S. P., J. A., Sz.-H. E., H. E., F. K., R. B., M. T. A cikk végleges változatát valamennyi szerző elolvasta és jóváhagyta.

Érdekeltségek: A szerzőknek nincsenek érdekeltségeik.

\section{Köszönetnyilvánítás}

Köszönettel tartozunk a résztvevő́knek, akik válaszaikkal segítették a közlemény létrejöttét. Köszönet a részt vevő munkatársaknak, hogy idejüket és szakértelmüket adták a munka során.

\section{Irodalom}

[1] Knowles SR, Graff LA, Wilding H, et al. Quality of life in inflammatory bowel disease: a systematic review and meta-analyses Part I. Inflamm Bowel Dis. 2018; 24: 742-751.

[2] Sajadinejad MS, Asgari K, Molavi H, et al. Psychological issues in inflammatory bowel disease: an overview. Gastroenterol Res Pract. 2012; 2012: 106502 .

[3] Bhamre R, Sawrav S, Adarkar S, et al. Psychiatric comorbidities in patients with inflammatory bowel disease. Indian J Gastroenterol. 2018; 37: 307-312.

[4] Häuser W, Janke KH, Klump B, et al. Anxiety and depression in patients with inflammatory bowel disease: comparisons with chronic liver disease patients and the general population. Inflamm Bowel Dis. 2011; 17: 621-632.

[5] Goodhand JR, Wahed M, Mawdsley JE, et al. Mood disorders in inflammatory bowel disease: relation to diagnosis, disease activity, perceived stress, and other factors. Inflamm Bowel Dis. 2012; 18: 2301-2309.

[6] Keefer L, Kane, SV. Considering the bidirectional pathways between depression and IBD: recommendations for comprehensive IBD care. Gastroenterol Hepatol (NY). 2017; 13: 164-169.

[7] Nowakowski, J, Chrobak AA, Dudek D. Psychiatric illnesses in inflammatory bowel diseases - psychiatric comorbidity and biological underpinnings. [Zaburzenia psychiczne w nieswoistych zapaleniach jelit - współistniejące zaburzenia psychiczne i mech- 
anizmy biologiczne.] Psychiatr Pol. 2016; 50: 1157-1166. [Polish]

[8] Walker JR, Ediger JP, Graff LA, et al. The Manitoba IBD cohort study: a population-based study of the prevalence of lifetime and 12 -month anxiety and mood disorders. Am J Gastroenterol. 2008; 103: 1989-1997.

[9] Neuendorf R, Harding A, Stello N, et al. Depression and anxiety in patients with inflammatory bowel disease: a systematic review. J Psychosom Res. 2016; 87: 70-80.

[10] Ben Thabet J, Charfi N, Mnif L, et al. Emotional disorders and inflammatory bowel disease. [Troubles émotionnels associés aux maladies inflammatoires chroniques de l'intestin.] Tunis Med. 2012; 90: 557-563. [French]

[11] Mojtabai R, Olfson M, Han B. National trends in the prevalence and treatment of depression in adolescents and young adults. Pediatrics 2016; 138: e20161878.

[12] Weinberger AH, Gbedemah M, Martinez AM, et al. Trends in depression prevalence in the USA from 2005 to 2015: widening disparities in vulnerable groups. Psychol Med. 2018; 48: 13081315.

[13] Walker J, Burke K, Wanat M, et al. The prevalence of depression in general hospital inpatients: a systematic review and meta-analysis of interview-based studies. Psychol Med. 2018; 48: 22852298.

[14] Hashash JG, Vachon A, Ramos Rivers C, et al. Predictors of suicidal ideation among IBD outpatients. J Clin Gastroenterol. 2019; 53: e41-e45.

[15] Litster B, Bernstein CN, Graff LA, et al. Validation of the PHQ 9 for suicidal ideation in persons with inflammatory bowel disease. Inflamm Bowel Dis. 2018; 24: 1641-1648.

[16] Kroenke K, Spitzer RL, Williams JB. The PHQ-9: Validity of a brief depression severity measure. J Gen Intern Med. 2001; 16: 606-613.

[17] Patient Health Questionnaire-9 (PHQ-9). Questionnaire about depression. [Minden a PHQ-9-ről: Beteg-egészségügyi kérdő́iv a depresszióról.] Available from: http://www.multiculturalmentalhealth.ca/wp-content/uploads/2013/11/PHQ-9-Hungarian.pdf [accessed: March 13, 2020]. [Hungarian]

[18] Byrne G, Rosenfeld G, Leung Y, et al. Prevalence of anxiety and depression in patients with inflammatory bowel disease. Can J Gastroenterol Hepatol. 2017; 2017: 6496727.

[19] Perczel Forintos D, Rózsa S, Kopp M. An investigation of the short version of the Beck Hopelessness Scale in a national representative survey in Hungary. [A Beck-féle Reménytelenség Skála rövidített változatának vizsgálata Magyarországon egy országos reprezentatív felmérés tükrében.] Psych Hung. 2007; 22: 375389. [Hungarian]

[20] Irvine EJ, Zhou Q, Thompson AK. The Short Inflammatory Bowel Disease Questionnaire: a quality of life instrument for community physicians managing inflammatory bowel disease. CCRPT Investigators. Canadian Crohn's Relapse Prevention Trial. Am J Gastroenterol. 1996; 91: 1571-1578.

[21] Pallis AG, Mouzas IA, Vlachonikolis IG. The Inflammatory Bowel Disease Questionnaire: a review of its national validation studies. Inflamm Bowel Dis. 2004; 10: 261-269.

[22] Graff, LA, Walker JR, Bernstein CN. Depression and anxiety in inflammatory bowel disease: a review of comorbidity and management. Inflamm Bowel Dis. 2009; 15: 1105-1118.
[23] Fuller-Thomson E, Sulman J. Depression and inflammatory bowel disease: findings from two nationally representative Canadian surveys. Inflamm Bowel Dis. 2006; 12: 697-707.

[24] Malham M, Jakobsen C, Paerregaard A, et al. The incidence of cancer and mortality in paediatric onset inflammatory bowel disease in Denmark and Finland during a 23 -year period: a population-based study. Aliment Pharmacol Ther. 2019; 50: 33-39.

[25] Zhang C, Byrne G, Lee T, et al. Incidence of suicide in inflammatory bowel disease: a systematic review and meta-analysis. J Can Assoc Gastroenterol. 2018; 1: 107-114.

[26] Faust AH, Halpern LF, Danoff-Burg S, et al. Psychosocial factors contributing to inflammatory bowel disease activity and healthrelated quality of life. Gastroenterol Hepatol (NY). 2012; 8: 173-181.

[27] Geiss T, Schaefert RM, Berens S, et al. Risk of depression in patients with inflammatory bowel disease. J Dig Dis. 2018; 19: 456-467.

[28] Alexakis C, Kumar S, Saxena S, et al. Systematic review with meta-analysis: the impact of a depressive state on disease course in adult inflammatory bowel disease. Aliment Pharmacol Ther. 2017; 46: 225-235.

[29] Stapersma L, van den Brink G, Szigethy EM, et al. Systematic review with meta-analysis: anxiety and depression in children and adolescents with inflammatory bowel disease. Aliment Pharmacol Ther. 2018; 48: 496-506.

[30] Health status of the European population in 2014. [A 2014-ben végrehajtott európai lakossági egészségfelmérés eredményei.] Központi Statisztikai Hivatal, Budapest, 2018. Available from: http://www.ksh.hu/docs/hun/xftp/idoszaki/elef/elef2014_ osszefoglalo.pdf [accessed: March 16, 2020]. [Hungarian]

[31] Nagy B, Laczkóné Mayer R. Specific quality of life factors in patients with inflammatory bowel disease. [Specifikus életminőségjellemző́k egészségpszichológiai szempontú vizsgálata gyulladásos bélbetegségben szenvedő betegek körében.] Orv Hetil. 2012; 153: 1511-1519. [Hungarian]

[32] Coates MD, Seth N, Clarke K, et al. Opioid analgesics do not improve abdominal pain or quality of life in Crohn's Disease. Dig Dis Sci. 2020; 65: 2379-2387. [Epub 2019 Nov 22]

[33] Navabi S, Gorrepati VS, Yadav S, et al. Influences and impact of anxiety and depression in the setting of inflammatory bowel disease. Inflamm Bowel Dis. 2018; 24: 2303-2308.

[34] Kovács Z, Kovács F. Depressive and anxiety symptoms, dysfunctional attitudes and social aspects in irritable bowel syndrome and inflammatory bowel disease. Int J Psychiatry Med. 2007; 37: 245-255.

[35] Bernstein CN. Psychological stress and depression: risk factors for IBD? Dig Dis. 2016; 34: 58-63.

[36] Lewis K, Marrie RA, Bernstein CN, et al. The prevalence and risk factors of undiagnosed depression and anxiety disorders among patients with inflammatory bowel disease. Inflamm Bowel Dis. 2019 ; 25 : 1674-1680.

(Molnár Tamás dr., Szeged, Korányi fasor 8-10., 6720 e-mail: molnar.tamas@med.u-szeged.hu)

A cikk a Creative Commons Attribution 4.0 International License (https://creativecommons.org/licenses/by/4.0/) feltételei szerint publikált Open Access közlemény, melynek szellemében a cikk bármilyen médiumban szabadon felhasználható, megosztható és újraközölhetö, feltéve, hogy az eredeti szerző és a közlés helye, illetve a CC License linkje és az esetlegesen végrehajtott módosítások feltüntetésre kerülnek. (SID_1) 